\title{
Role of convection in hydration of tropical UTLS: implication of AURA MLS long-term observations
}

\author{
S. Jain, A. R. Jain, and T. K. Mandal \\ Radio and Atmospheric Science Division, CSIR-National Physical Laboratory, New Delhi-110012, India \\ Correspondence to: T. K. Mandal (tuhin@nplindia.org)
}

Received: 21 January 2013 - Revised: 17 April 2013 - Accepted: 25 April 2013 - Published: 24 May 2013

\begin{abstract}
This paper addresses various characteristic features associated with the hydration of the tropical upper troposphere and lower stratosphere (UTLS) in association with the boreal monsoonal convective activity occurring over three different tropical regions viz. Asian region, American region and African region. Analysis of water vapor mixing ratio (WVMR) data obtained from AURA MLS (v3.3), ISCCP D1 cloud top pressure data and outgoing long-wave radiation data (OLR) from NOAA reanalysis has brought out two significant results. Firstly, high altitude clouds and high WVMR regions are mostly associated with the low OLR region. Convection over Asian region is very deep and spread over a large geographical area as compared to African or American region. Magnitude of WVMR in the pressure range of $261.0-146.8 \mathrm{hPa}$ is observed to be higher over the Asian region, whereas, close to the tropopause level $(\sim 100 \mathrm{hPa})$ it is comparable or more over the American region as compared to Asian and African regions. Secondly, the vertical ascent rate of water vapour obtained from AURA MLS data suggest that convection associated transport might have dominated up to $146.8-121.2 \mathrm{hPa}$ in addition to slow large scale diabatic transport, which appears to be prominent above the pressure range of $100-82.5 \mathrm{hPa}$. Within the pressure levels of 121.2 to $82.5 \mathrm{hPa}$, the influence of convective transport appears to be gradually decreasing. However, there are other possible processes like ice sublimation or cirrus jumping which could contribute to the hydration of the tropical lower stratosphere. Present analysis has, thus, brought out the significance of convection in water vapour transport and distribution in the tropical UTLS.

Another interesting feature which is observed is the anomalous increase in temperature during boreal winters (November-April) over all three convective regions. Such phenomenon is only observed within the pressure range of
\end{abstract}

100.0-261.0 hPa; however it is relatively weaker for levels $>177.8 \mathrm{hPa}$.

Keywords. Atmospheric composition and structure (troposphere-composition and chemistry) - Meteorology and atmospheric dynamics (convective processes; synopticscale meteorology)

\section{Introduction}

Water vapour is an important greenhouse gas which traps the infrared outgoing long-wave radiation (OLR) and raises the temperature of the troposphere. It also exhibits cooling effect which leads to the extremely low temperatures at lower stratospheric heights (Foster and Shine, 1999) and, hence, affects the balance between radiative heating and adiabatic cooling occurring in the upper troposphere and lower stratosphere (UTLS). Stratospheric water vapour concentration acts as a planetary source of $\mathrm{HO}_{\mathrm{x}}$ and initiates enhanced ozone depletion (Solomon et al., 1986). Therefore, the sources which lead to the availability of water vapour in tropical lower stratosphere and hydration of UTLS needs to be examined in order to better understand and predict the future global climatic conditions.

Most of the stratospheric-tropospheric exchange and entry of water vapour from the upper troposphere to lower stratosphere occurs through tropical tropopause layer (Brewer, 1949; Holton et al., 1995; Highwood and Hoskins, 1998; Fueglistaler et al., 2009). Major processes which control the concentration of water vapour in the UTLS region are (1) A fast convective transport due to convection via an upward branch of the Hadley circulation (Sherwood and Dessler, 2001; Gettelman et al., 2002) (2) Slow diabatic ascent of water vapour which is associated with the ascending branch 
of the Brewer-Dobson circulation (Holton and Gettelman, 2001; Fueglistaler et al., 2005).

Other mechanisms which may participate in the hydration of the tropical lower stratosphere (TLS) are (1) a nonhydrostatic process which includes the injection of ice crystals in the TLS by land convective overshooting followed by their sublimation (Nielsen et al., 2007; Corti et al., 2008; De Reus et al., 2008; Khaykin et al., 2009). Sublimation of insitu ice crystals formed in the UTLS region due to low temperature may also occur under favorable conditions (2) Cirrus jumping due to gravity wave breaking as discussed by Wang $(2003,2004,2007)$ and Wang et al. (2009) and ice crystals carried by the same are also likely to undergo sublimation and (3) production of $\mathrm{H}_{2} \mathrm{O}$ via methane oxidisation. In addition, horizontal transport can also play a significant role in redistribution of water vapour in this region.

Convection plays an important role in the transport of water vapour from sea surface level to tropospheric heights. It was suggested that a large amount of water vapour is transported vertically or quasi-vertically by convection up to a barrier height (Folkins et al., 1999) and around $99 \%$ of the water vapour detrainment occurs near $\sim 12-14 \mathrm{~km}$ which is much below the tropopause level $(\sim 16 \mathrm{~km})$. These studies have revealed that only around $1 \%$ of convective mass flux penetrates the tropical tropopause layer and largely affects the stratospheric properties (Gettelman et al., 2002; Dessler, 2002; Dessler and Sherwood, 2004). These short-term, overshooting convective events are found to be occurring during the Asian summer and monsoon period when the moist air is introduced in the lower stratosphere via monsoon's upper level anticyclone (Bannister et al., 2004; James et al., 2008). Therefore, the water vapour abundance in the UTLS region must be examined during the boreal monsoon season in order to determine the influence of convection related transport in the UTLS.

Occurrence of lower temperatures near tropical tropopause (Jain et al., 2006, 2010, 2011) strongly influences the water vapour transport in the TLS and plays a key role in controlling the amount of water vapour ascending diabatically. Annual cycles of temperature close to the tropopause level and water vapour in TLS were found to be closely related (Mote, 1995; Mote et al., 1996). Recently, a long term data analysis of temperature and water vapour in UTLS zone is carried out over the Bay of Bengal and Indonesian-Australian West Pacific region (IAWPR) by Panwar et al. (2012). These authors have identified the convective regions using OLR data and suggested that the time period for which OLR is minimum, the water vapour is maximum (up to $\sim 147 \mathrm{hPa}$ ) over the Bay of Bengal region. They have shown the influence of convection in water vapour transport over Asian region. However, the relative role of different convective regions in hydration of TLS during boreal summer monsoon season has not been discussed by Panwar et al. (2012).

In this paper, an analysis is carried out indicating the vertical transport of water vapour in the UTLS region, over three independent tropical convective zones. Long term high resolution water vapor mixing ratio (WVMR) and temperature data obtained from EOS AURA MLS (August 2004December 2010) are used here in addition to wind data from ERA-Interim reanalysis, OLR data from NOAA and ISCCP D1 cloud top pressure data. In this paper, an attempt has been made to better understand the hydration of TLS and associated troposphere-stratosphere exchange processes. Following are the main objectives of this study:

- Identification of the tropical convective regions which lead to the hydration of the tropical UTLS during Northern Hemisphere summer/monsoon.

- Study of the various characteristic features of WVMR and temperature distribution in UTLS.

- Influence of convection on water vapour transport from troposphere to stratosphere over the identified convective regions.

\section{Database and methodology}

Convective regions are determined by using OLR data. Interpolated OLR data from NOAA is used for the period of 13 August 2004 (start of MLS) to 31 December 2010. Monthly mean OLR $\left(\mathrm{W} \mathrm{m}^{-2}\right)$ data is binned into $2.5 \times 2.5 \mathrm{de}-$ gree latitude-longitude grid over the tropical region $(-40$ to $40^{\circ} \mathrm{N},-180$ to $180^{\circ} \mathrm{E}$ ) for June to September 2007. Gaps in OLR data from NCAR archives are filled with spatial and temporal interpolation. Description of the interpolation technique and the complete OLR dataset is given by Liebmann and Smith (1996) in details. Occurrence of strong convective events is identified over three regions, namely the Asian region $\left(5^{\circ} \mathrm{S}-30^{\circ} \mathrm{N}, 70-150^{\circ} \mathrm{E}\right)$, the African region $\left(0-15^{\circ} \mathrm{N}\right.$, $\left.0-30^{\circ} \mathrm{E}\right)$ and American region $\left(5-20^{\circ} \mathrm{N}, 70-110^{\circ} \mathrm{W}\right)$ of the tropical region. The presence of convective clouds and enhanced water vapour over identified convective regions is studied using ISCCP D1 and EOS AURA MLS spacecraft data, respectively.

International Satellite Cloud Climatology Project (ISCCP) Stage D1 3-Hourly Cloud Product data is analysed for the period of June-September 2007 over the tropical region. ISCCP D1 data provide the cloud top pressure binned over an equalarea grid with $280 \mathrm{~km}$ resolution along latitude and longitude at every $3 \mathrm{~h}$ interval. Most of the deep penetrating convective activity over the tropical region occurs during the daytime (Gettelman et al., 2002). Therefore, monthly mean cloud top pressure (equivalent to cloud top height) of deep convective cloud is plotted using local daytime data. Local daytime (solar zenith angle $\leq 78.5^{\circ}$ ) and deep convective clouds (cloud optical thickness $>23$ and $<379$ ) are identified using ISCCP classification of cloud system (Rossow and Schiffer, 1999; Rossow et al., 1996). The data points in the graphs are shown at centre latitude-longitude position of the equalarea grid. The percentage occurrence frequency of the clouds 


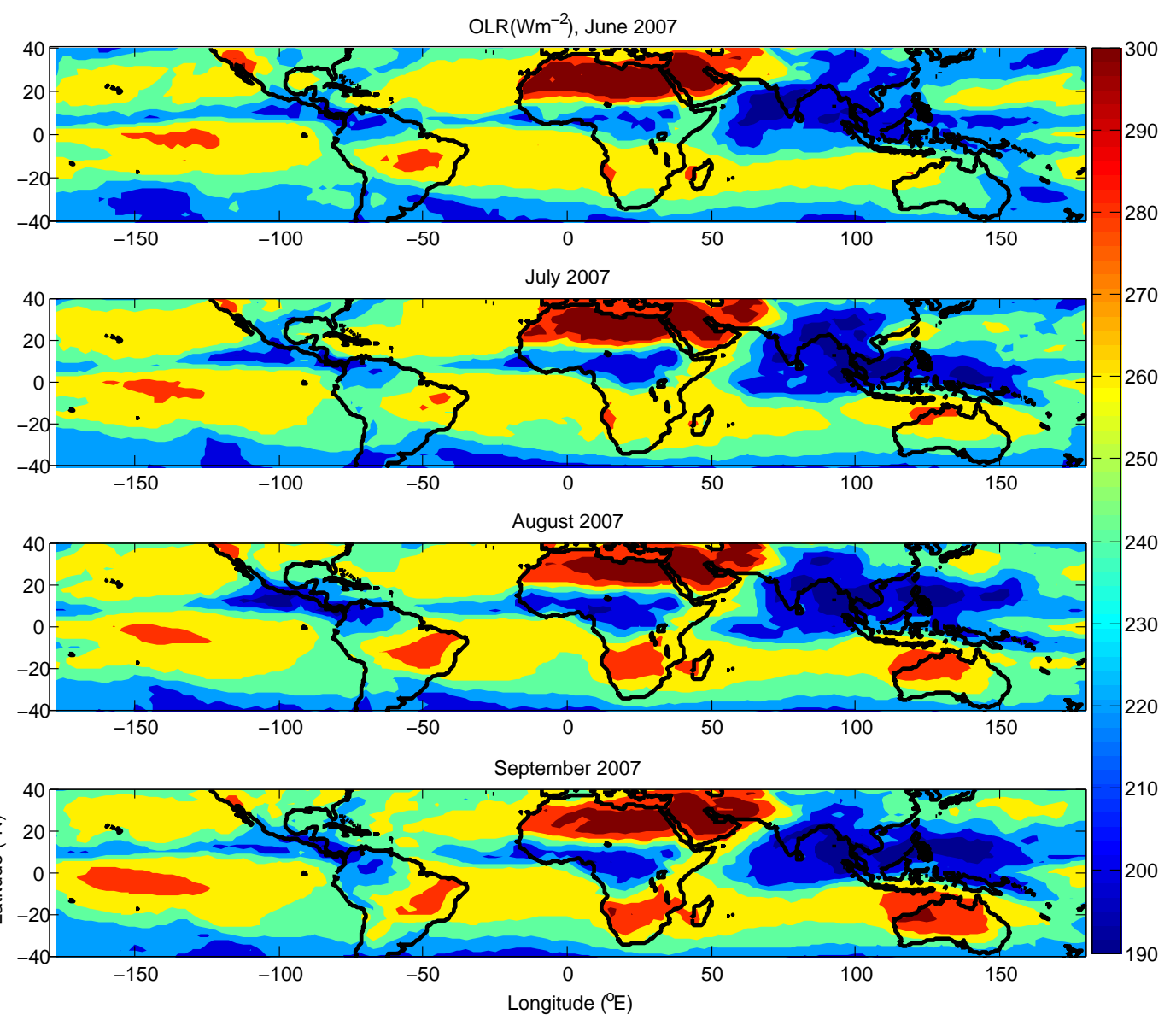

Fig. 1a. Monthly mean OLR $\left(\mathrm{W} \mathrm{m}^{-2}\right)$ from NOAA for the time period of June to September 2007.

crossing a certain pressure level for every grid bin is also analysed for the period of June to September 2007. Cloud occurrence frequency $(\%)$ of the clouds at particular pressure level (for example $<150 \mathrm{hPa}$ ) is defined as the total number of convective cloud pixels with pressure less than or equal to $150 \mathrm{hPa}$ divided by the total number of convective cloud pixels available in a grid bin. This process is repeated for every grid bin and for various pressure levels viz. $<150,150$ 200, 200-250, 250-350 and > 350 hPa for June to September 2007.

For the present study, WVMR and temperature data are obtained from Microwave Limb Sounder (MLS), EOS AURA spacecraft. MLS Level 2, Version 3.3 Standard atmospheric products for WVMR and temperature data are used in the present analysis. Validation of the WVMR data was done by Lambert et al. (2007) and validation of the temperature data was done by Schwartz et al. (2008) in detail. MLS data are available at different pressure levels viz. 56.2, 68.1, 82.5, $100,121.2,146.8,177.8,215.4$ and $216 \mathrm{hPa}$ of upper tropospheric and lower stratospheric region. The temporal analysis of temperature and WVMR has been done using around 7 years of MLS data (August 2004-December 2010) over three convective regions of tropical region. A daily average of the data is taken to form the time series of WVMR and temperature over specific latitude-longitude sector. WVMR and temperature time series smoothing is done by taking a 13 day running mean to avoid the day to day fluctuations in data values. The spatial analysis of WVMR is carried out with a resolution of $2 \times 2$ degree latitude-longitude grid over the tropical region using monthly averaged data.

\section{Results}

\subsection{Occurrence of convection}

Generally, the strong convection occurs over the regions for which OLR $<220 \mathrm{~W} \mathrm{~m}^{-2}$ (Wild and Roeckner, 2006) and the convective regions are expected to possess more highaltitude convective clouds and enhanced water vapour (Ricaud et al., 2007). 

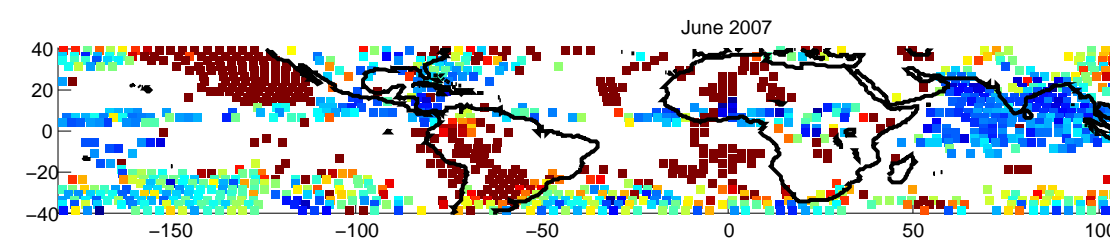

Cloud top pressure (hPa)
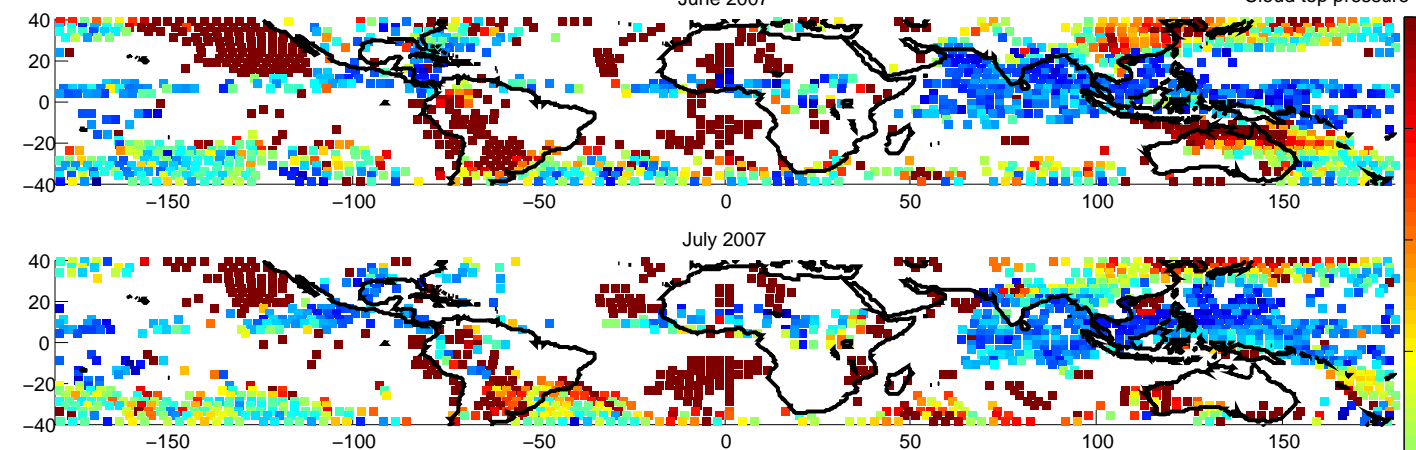

July 2007

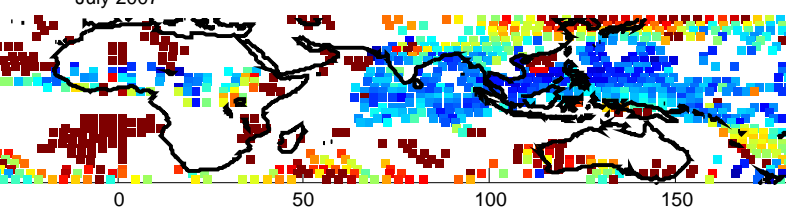

August 2007

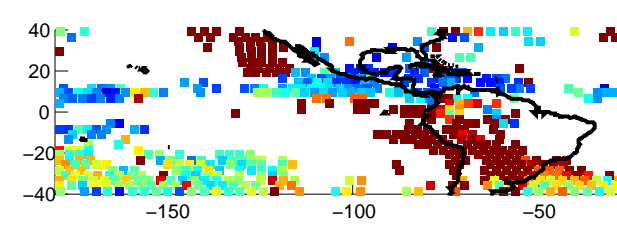

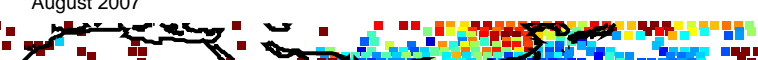
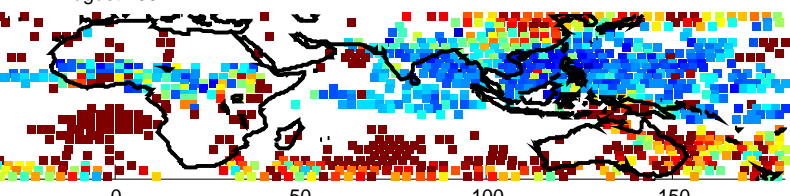

September 2007

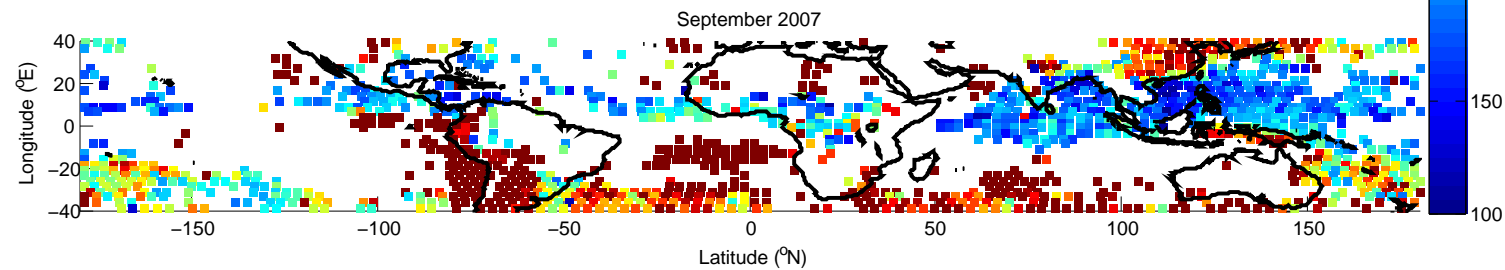

Fig. 1b. Monthly mean daytime convective cloud top pressure (hPa) from ISCCP D1 data for the time period of June to September 2007. White colour indicates the missing or no data.

\subsubsection{Identification of the convective regions using OLR data}

Figure 1a shows the spatial distribution of monthly mean OLR over the tropical region for the period of JuneSeptember 2007. Three independent low OLR regions (< $220 \mathrm{~W} \mathrm{~m}^{-2}$ ) i.e., organised convective regions are observed over the tropics, viz., Asian region $\left(5^{\circ} \mathrm{S}-30^{\circ} \mathrm{N}, 70-150^{\circ} \mathrm{E}\right)$, African region $\left(0-15^{\circ} \mathrm{N}, 0-30^{\circ} \mathrm{E}\right)$ and American region (5$\left.20^{\circ} \mathrm{N}, 70-110^{\circ} \mathrm{W}\right)$. The convective regions contain a central region for which OLR is lowest and a gradual increase in OLR values is observed towards the peripheral region. These convective regions are asymmetric with respect to the equator and the major parts of the low OLR region are situated in the Northern Hemisphere during boreal monsoon period (June to September). No major spatial shift of the low OLR region is observed during the study period. The convection over Asian region is more intense (with OLR as low as $\sim 190 \mathrm{~W} \mathrm{~m}^{-2}$ ) and spread over a larger area as compared to American and African region.

\subsubsection{Convective cloud top pressure data}

Spatial distribution of ISCCP D1 cloud top pressure of daytime deep convective clouds has been used to understand the vertical extent of convection. In Fig. 1b, high altitude clouds with top pressure lying between $150-200 \mathrm{hPa}$ are clearly visible over a large geographical area of Asian, American and African region for the whole boreal monsoon period. Over the Asian region, cloud top pressure lower than $150 \mathrm{hPa}$ is observed to be over a large area in comparison with American or African region. Figures 1c and d show the percentage of daytime deep convective clouds with cloud top pressure $\leq 150 \mathrm{hPa}, 150-200 \mathrm{hPa}, 200-250 \mathrm{hPa}, 250$ $350 \mathrm{hPa}$ and $>350 \mathrm{hPa}$ for June to September 2007. It is evident from Figs. 1c and $\mathrm{d}$ that the deep convective clouds penetrating above 150 and $200 \mathrm{hPa}$ are more frequent and occur over a relatively larger area over the Asian region in comparison to the American and African region.

It may also be noted that the region of low OLR has overlapped the region of high altitude clouds. The cloud top pressure is observed to be lowest over the core convective region.

\subsection{Spatial distribution of water vapour mixing ratio}

Spatial distribution of AURA MLS WVMR has been examined as presence of enhanced moisture content over the low OLR region is considered as a proxy of convection. Figure 2a-b show the spatial distribution of monthly mean WVMR (ppmv) at different pressure levels viz. 261, 215.4, $177.8,146.8,121.2,100,82.5$ and $68.1 \mathrm{hPa}$ for the period of June-September 2007 over the tropical region. Large scale vertical transport and horizontal outflow of water vapour from convective regions is evident from Fig. 2a-b. Various 


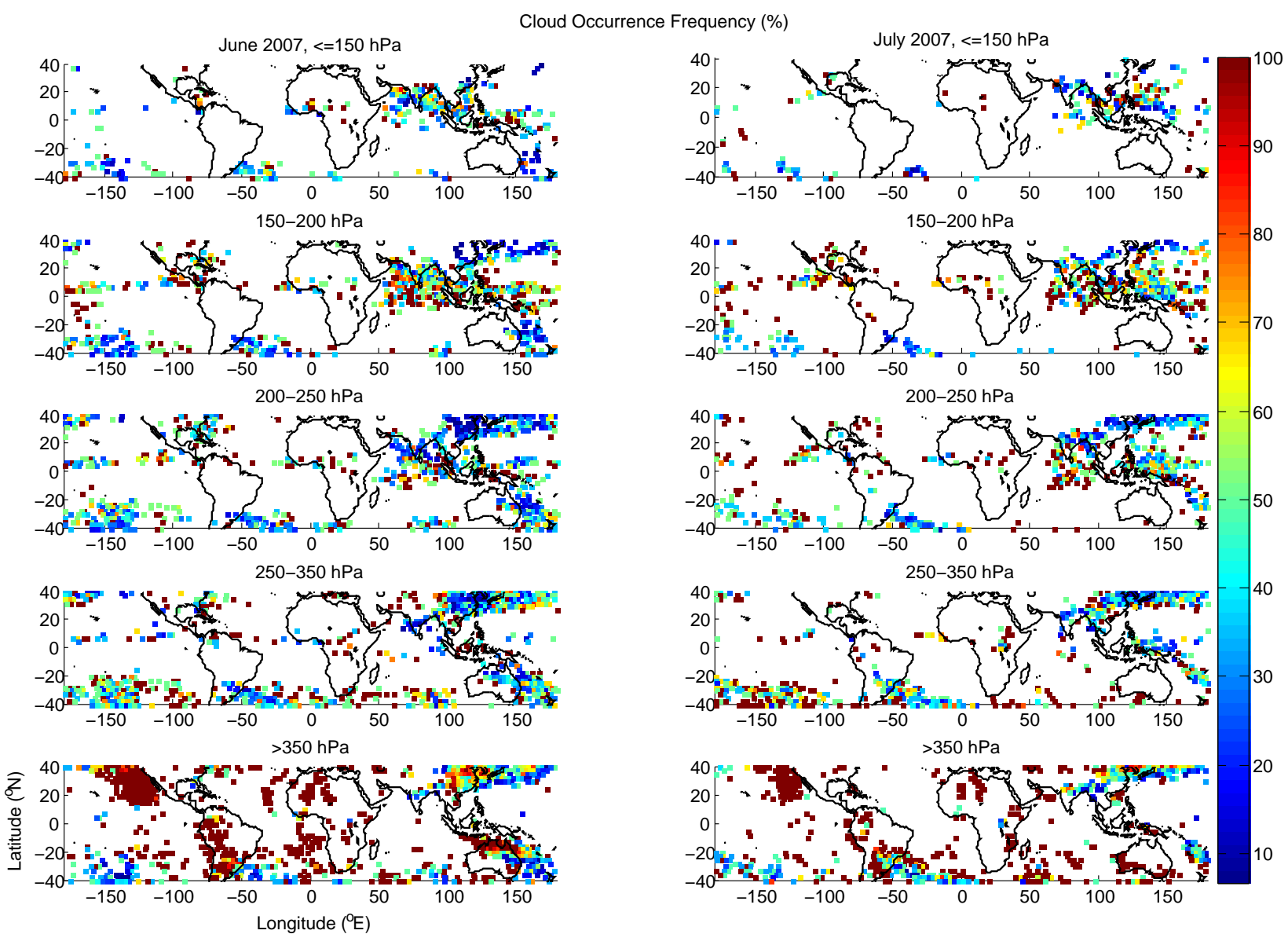

Fig. 1c. Daytime convective cloud occurrence frequency (\%) for different pressure levels viz. $\leq 150 \mathrm{hPa}, 150-200 \mathrm{hPa}, 200-250 \mathrm{hPa}, 250-$ $350 \mathrm{hPa}$ and $>350 \mathrm{hPa}$ from ISCCP D1 data for the time period of June to July 2007. White colour indicates the missing data or zero percentage occurrence value.

characteristic features of WVMR distribution and location of the high WVMR region with respect to the observations of low OLR are discussed below.

The three regions of high WVMR (200-500 ppmv) at 261.0-215.4 hPa are observed directly above low OLR zones and there exists a lot of similarity between the spatial coverage of these two parameters. The center of the convective region is found to be more moist than the neighbouring region which surrounds the convective area. The magnitude of the WVMR in the convective region is around two orders higher than the value outside the convective region at same pressure levels. Such a large increase in magnitude of WVMR only over a localized area suggests the occurrence of rapid convective transport of water vapour over a confined region. Thus, this suggests that a large amount of water vapour may be carried vertically or quasi vertically to the upper troposphere from convective regions underneath. This is to be noted that the centre of the low OLR region does not coincide with the centre of high WVMR for the pressure levels lower than $215.4 \mathrm{hPa}$ and maxima of WVMR lies on the northwest side of the low OLR region (see supplementary material).
The vertical transport of water vapour from $261.2 \mathrm{hPa}$ to $215.4 \mathrm{hPa}$ appears to be immediate as there is no substantial decrease in the magnitude of WVMR (order is same) between the two consecutive pressure levels. However, the magnitude of WVMR decreases by almost one order from $215.4 \mathrm{hPa}$ to $177.8 \mathrm{hPa}$. Only around $10-30 \%$ of water vapour travels upwards from $215.4 \mathrm{hPa}$ to $177.8 \mathrm{hPa}$ over the convective regions.

Magnitude of WVMR over the Asian region during the boreal monsoon period is much higher and spread over a larger area as compared to the other two regions for the pressure levels between $261.0 \mathrm{hPa}$ to $146.8 \mathrm{hPa}$ (Fig. 2b). It may be concluded from the above analysis involving OLR, cloud top pressure data and WVMR that the Asian region may be convectively more active than the other two regions and acts as a major source of upper tropospheric water vapour. Panwar et al. (2012) have also indicated that the Asian monsoon region contributes more to the hydration of tropical lower stratosphere.

One of the most interesting features of this study is that the relative contribution of different geographical regions 


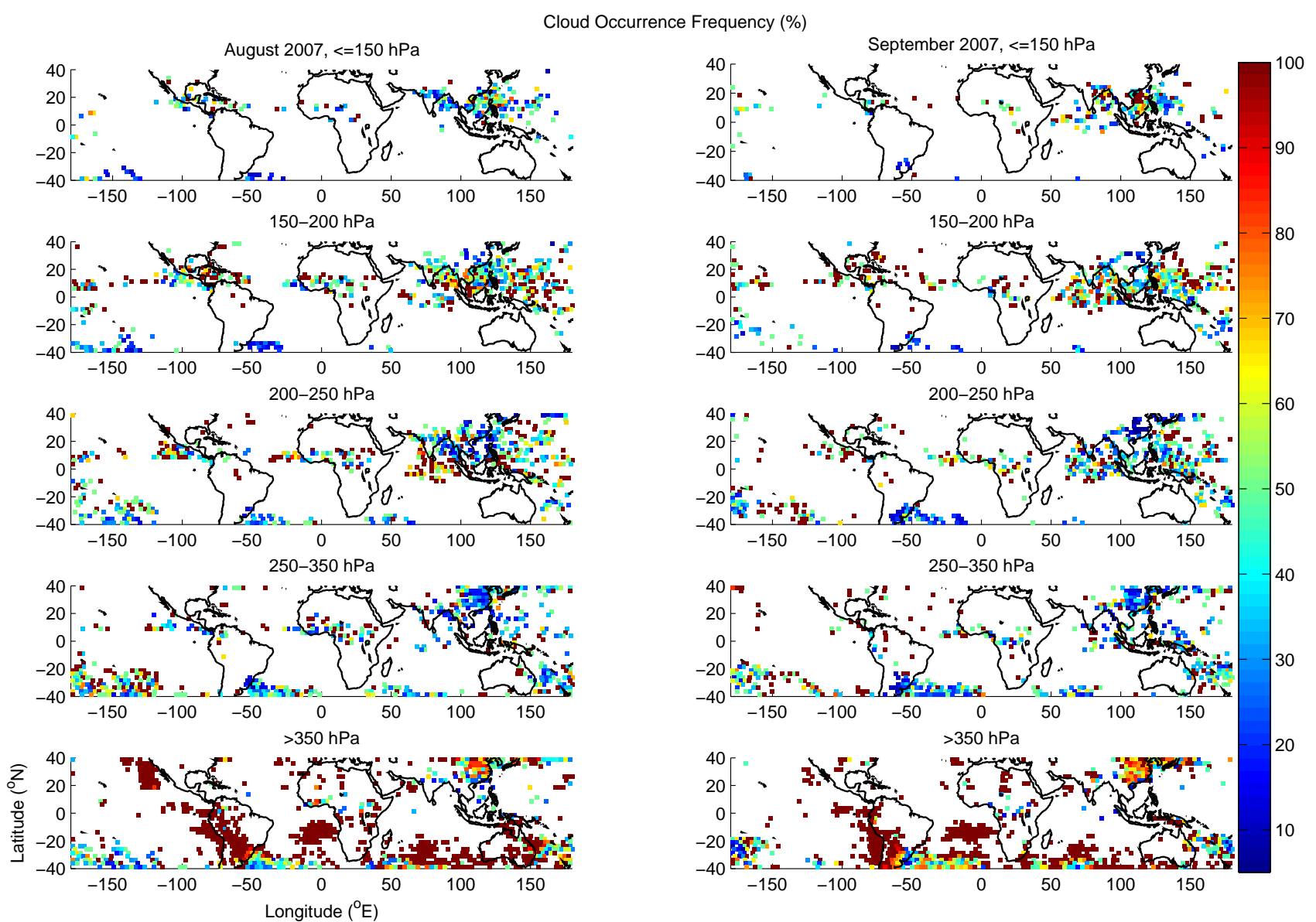

Fig. 1d. Same as Fig. 1c, but for August and September 2007.

in moistening UTLS appears to be varying with changing pressure levels. It has been already mentioned that at lower heights $(>121.2 \mathrm{hPa}$ ) Asian region contains more amount of water vapour in comparison with American and African region, whereas, at higher heights $(<121.2 \mathrm{hPa})$ WVMR over American region becomes comparable to the Asian region.

\subsection{Temporal distributions of water vapour mixing ra- tio and temperature}

The distribution of WVMR shows spatial heterogeneity over tropical regions. Figure $3 \mathrm{a}-\mathrm{c}$ shows the temporal variation of temperature, WVMR and OLR at different pressure levels of UTLS region. A $10 \times 20^{\circ}$ latitude-longitude grid is chosen over each convective region (Asian: $10-20^{\circ} \mathrm{N}, 80-100^{\circ} \mathrm{E}$; American: $10-20^{\circ} \mathrm{N}, 90-110^{\circ} \mathrm{W}$; African: $10-20^{\circ} \mathrm{N}, 10$ $\left.30^{\circ} \mathrm{E}\right)$ for the temporal analysis.

Seasonal variations in temperature, WVMR and OLR are depicted in Fig. 3a-c. OLR is minimum during boreal monsoon period (as also shown in Fig. 1a) and maximum during the winter period over all three regions. Maxima of WVMR at $146.8 \mathrm{hPa}$ occurs during boreal monsoon suggests that a large amount of water vapour appears at higher pressure lev- els of UTLS when OLR is low. WVMR shows seasonal contrast at all pressure levels varying from 146.8 to $56.2 \mathrm{hPa}$. This time series reveals that daily fluctuations in the WVMR are more for pressure levels greater than $100 \mathrm{hPa}$.

Seasonal variation in temperature is noticed only at heights above $100 \mathrm{hPa}$. Events of enhanced temperature are noted where temperature has increased and attained values even higher than the monsoon and the spring season during Northern Hemisphere winter period for pressure levels higher than $100 \mathrm{hPa}$. These anomalous peaks in temperature can be traced at various pressure levels (from 146.8 to $100 \mathrm{hPa}$ ) and in year to year variations over all three convective regions. This may be noted that this phenomenon appears to be initiated from lower heights ( $>146.8 \mathrm{hPa}$ ). Figure 4 shows the deviation of daily temperatures from the long term mean value of temperature (August 2004 to December 2010) from 82.5 to $261.0 \mathrm{hPa}$. An abrupt increase in temperature during boreal winters can be easily traced from 177.8 to $100 \mathrm{hPa}$. At pressure level $>177.8 \mathrm{hPa}$, this increment is relatively weaker.

A cross correlation between OLR (as low OLR is a proxy for convection) and WVMR time series is calculated to confirm the influence of convection in transportation of water 

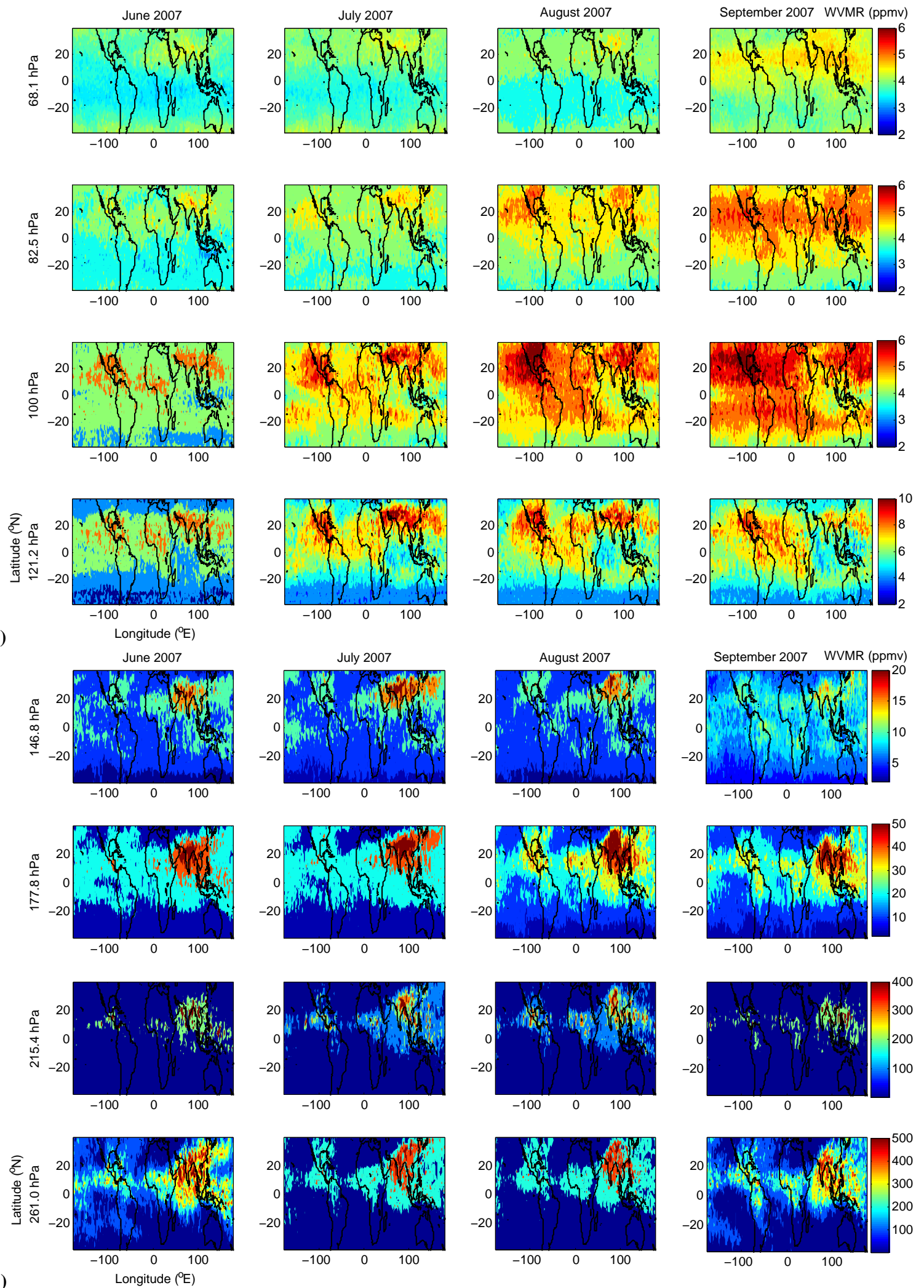

Fig. 2. Spatial distributions of monthly mean WVMR (ppmv) at (a) 121.2, 100, 82.5 and $68.1 \mathrm{hPa}$, (b) 261.2, 215.4, 177.8 and $146.8 \mathrm{hPa}$ from Aura MLS for June to September 2007. 


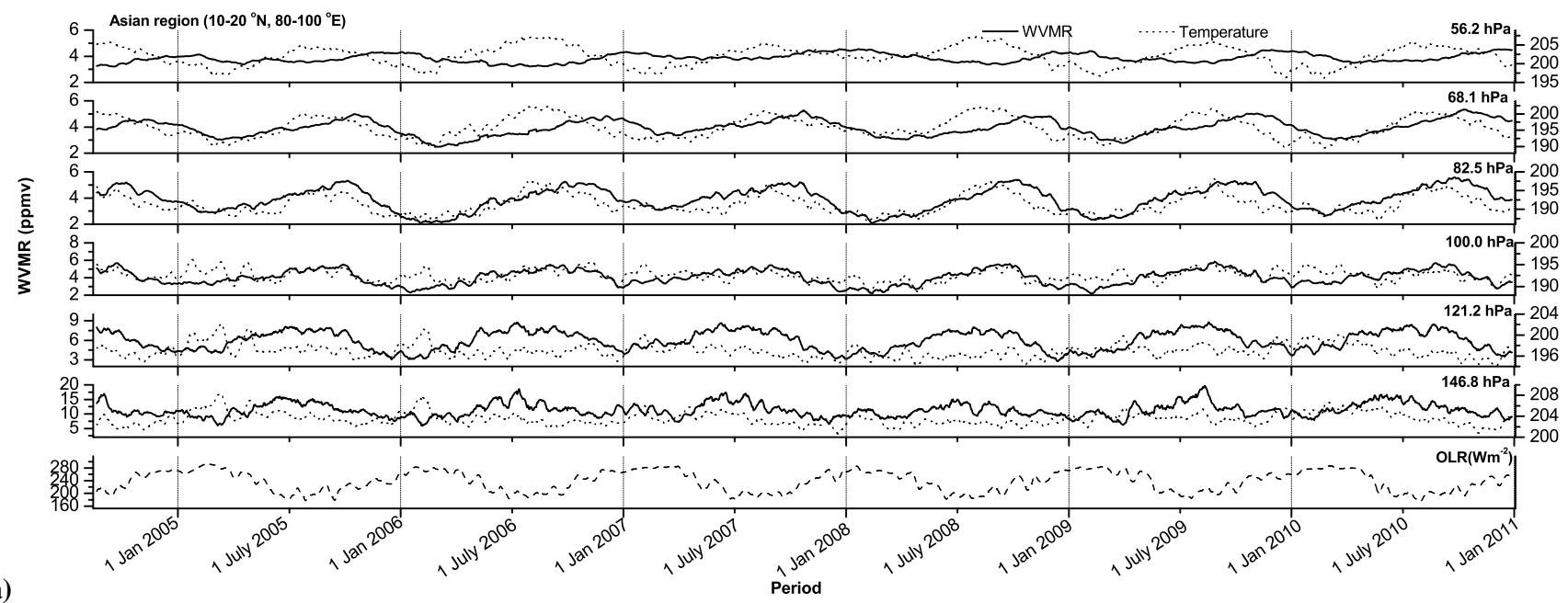

(a)

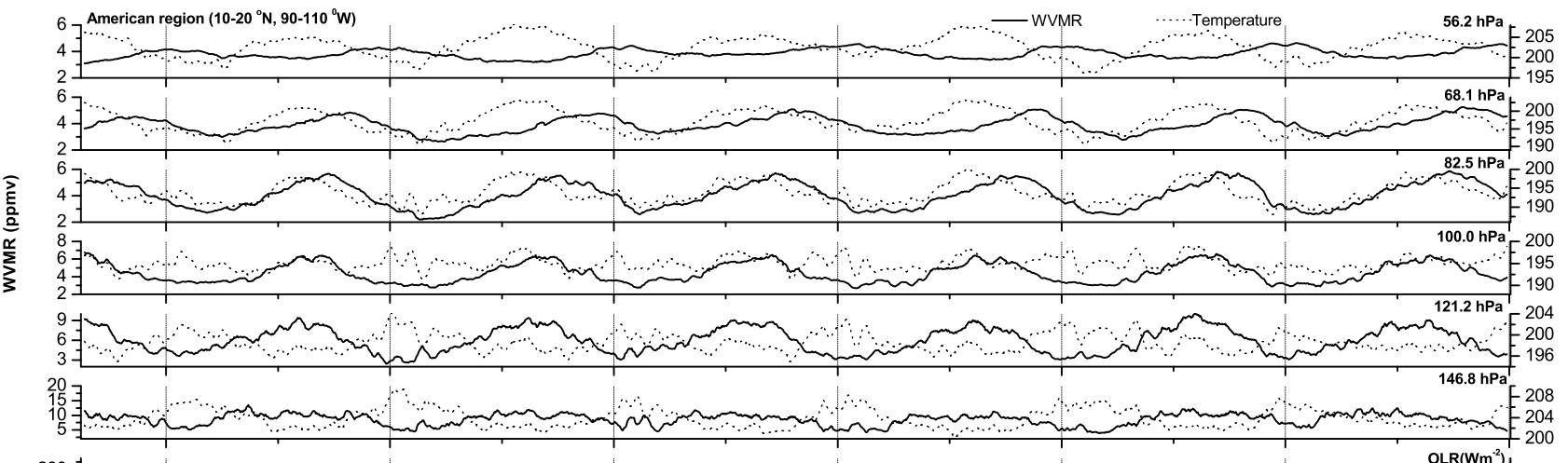

280 寿

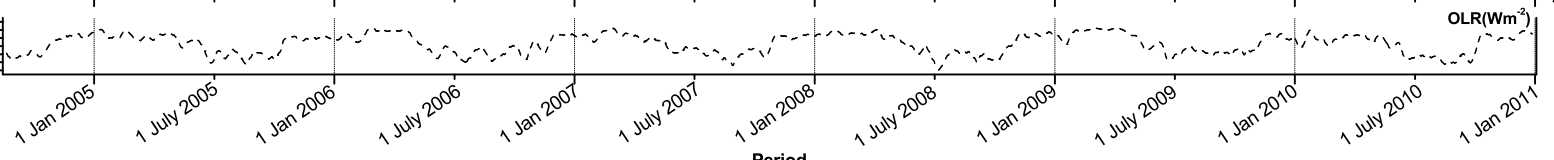

(b)

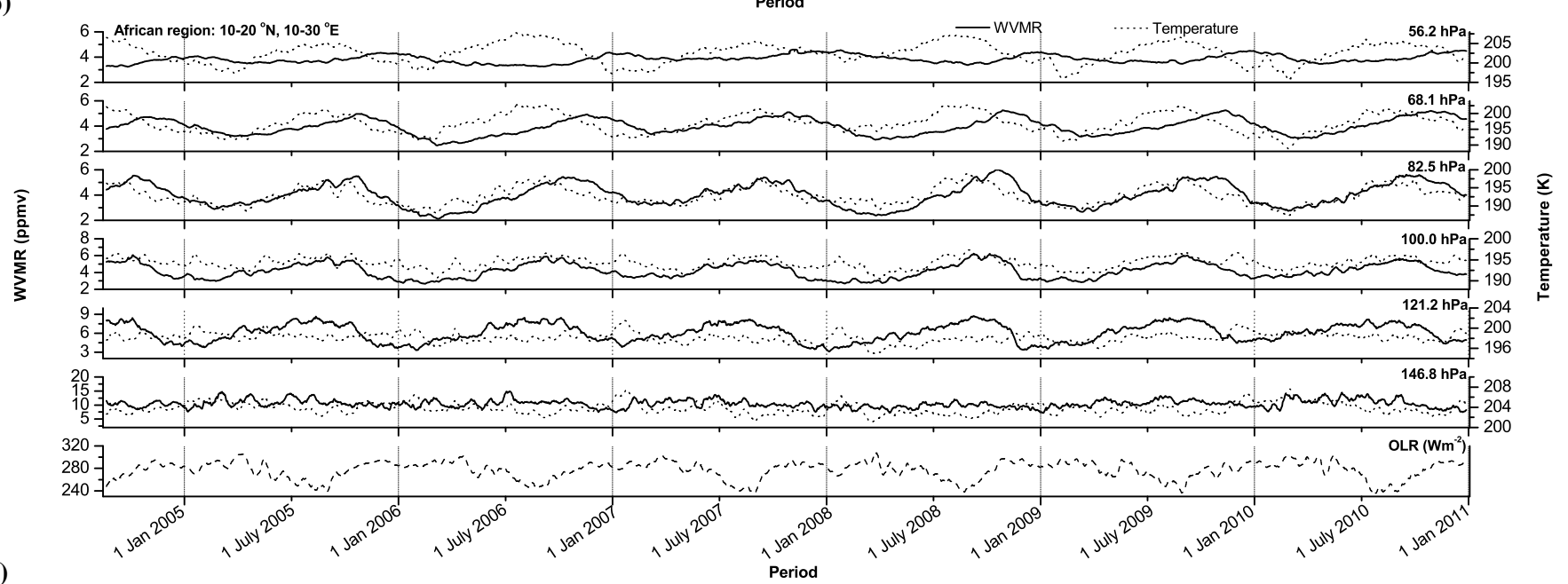

Fig. 3. Time series of WVMR and temperature from 19 August 2004 to 25 December 2010 at $146.8,121.2,100,82.5,68.1$ and $56.2 \mathrm{hPa}$ from AURA MLS over (a) Asian region, (b) American region, (c) African region. OLR time series over each of these regions are also shown in the bottom panel. 


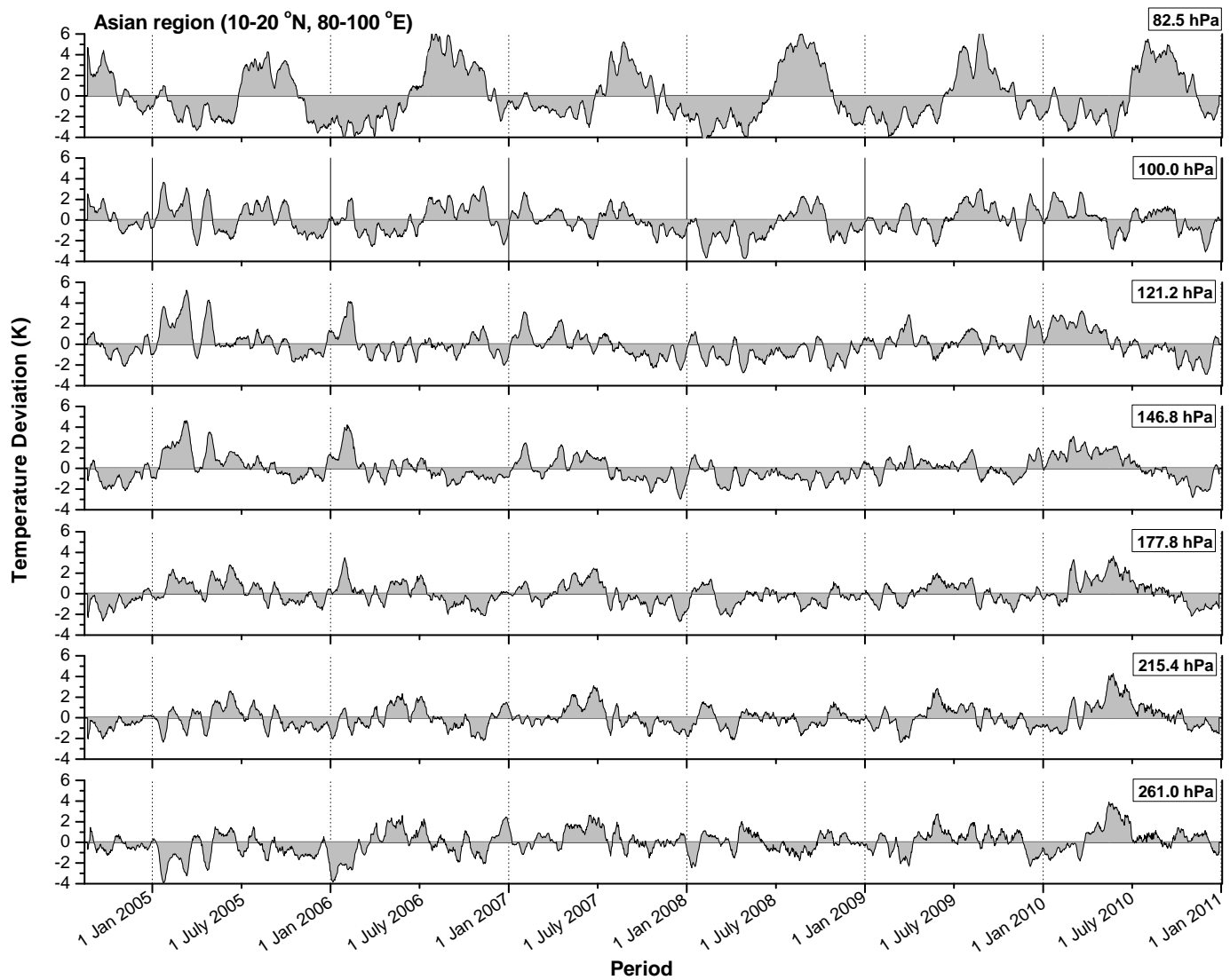

Fig. 4. Deviation of daily temperatures from the long term mean value of temperature (August 2004 to December 2010) at 261.0, 215.4, 177.8, 146.8, 121.2, 100.0 and $82.5 \mathrm{hPa}$ from 19 August 2004 to 25 December 2010 over the Asian region.

vapour at higher pressure levels (or lower heights) of UTLS. Figure 5 shows a cross-correlation function between OLR and WVMR time series at different pressure levels over all three convective regions. Since low OLR corresponds to enhanced convection activity which in turn gives rise to the enhanced amount of water vapour in tropical UTLS, so a negative correlation between WVMR and OLR is expected at zero lag values. Figure 5 shows that the water vapour is negatively correlated with OLR at around zero lag values for pressure levels up to 146.8-121.2 hPa. At higher pressure levels, WVMR time series precedes over the OLR time series. This suggests that there may exist a certain threshold value of low OLR which depicts the occurrence of intense convection over a region and before OLR further decreases and becomes minimum, a large scale transport of water vapour might have already started from this region. Wild and Roeckner (2006) and Ricaud et al. (2007) have also suggested the threshold value of OLR of the order of $220 \mathrm{~W} \mathrm{~m}^{-2}$. The negative peak of the cross-correlation function appears to be displaced by some positive lag at $100 \mathrm{hPa}$. This is because of the fact that WVMR time series gets delayed with the decreasing pressure levels.
To further study the delay in WVMR time series and the influence of convective transport of water vapour, a cross correlation analysis has been carried out over the three convective regions using a daily time series of data from $\mathrm{Au}-$ gust 2004 to December 2010. Figure 6 shows the cross correlation function of WVMR (solid line) calculated by using the two WVMR time series at consecutive pressure levels i.e., between $146.8-121.2 \mathrm{hPa}, 121.2-100 \mathrm{hPa}$ and so on. The cross-correlation function of WVMR between $146.8 \mathrm{hPa}$ and 121.2 $\mathrm{hPa}$ peaks at zero lag value over Asian and American region. This shows that the changes in WVMR time series at $146.8 \mathrm{hPa}$ and $121.2 \mathrm{hPa}$ are almost simultaneous over these regions, which could be due to a fast convective ascent of water vapour from 146.8 to $121.2 \mathrm{hPa}$. At the higher altitudes $(<121.2 \mathrm{hPa})$, cross-correlation function peaks at a certain lag value. This suggests that the ascent of water vapour becomes comparatively slow at lower pressure levels. The lag value is found to be increasing minimally to 2 and 5 days over Asian region and American region, respectively, from 121.2 to $100 \mathrm{hPa}$, but a sharp increase in lag value is observed from 100 to $82.5 \mathrm{hPa}$ pressure levels. The total delay in WVMR time series from 121.2 to $56.2 \mathrm{hPa}$ is 126,132 and 117 over Asian, American and African region, respectively 


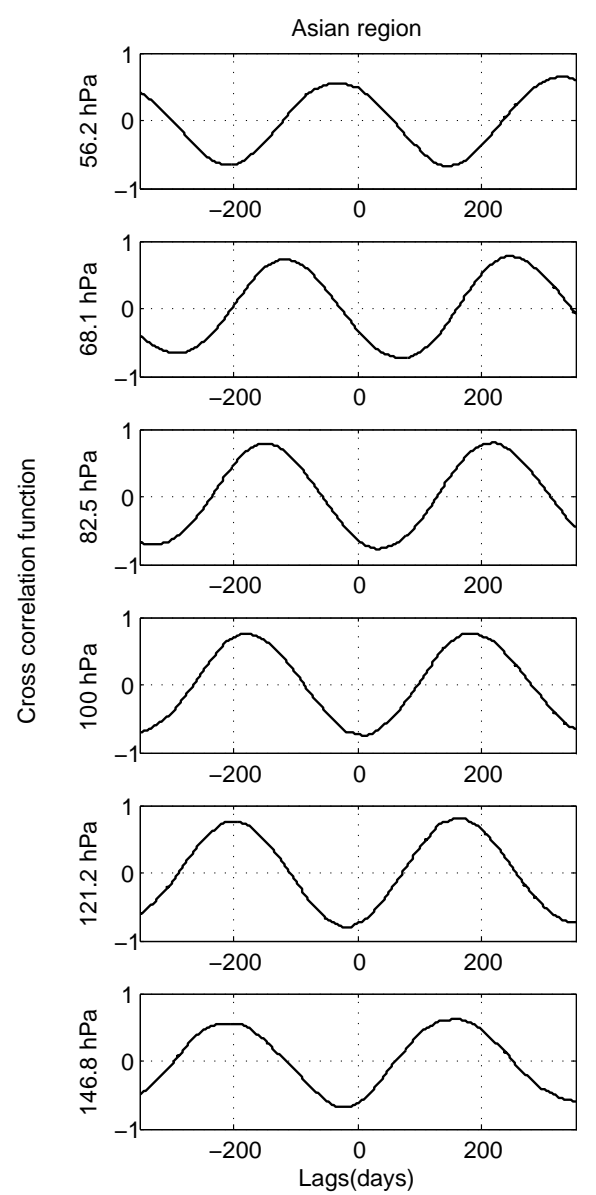

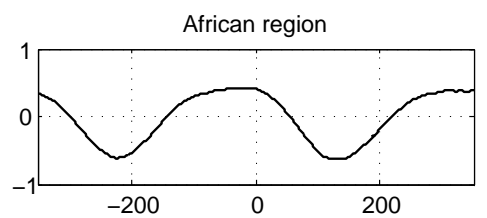
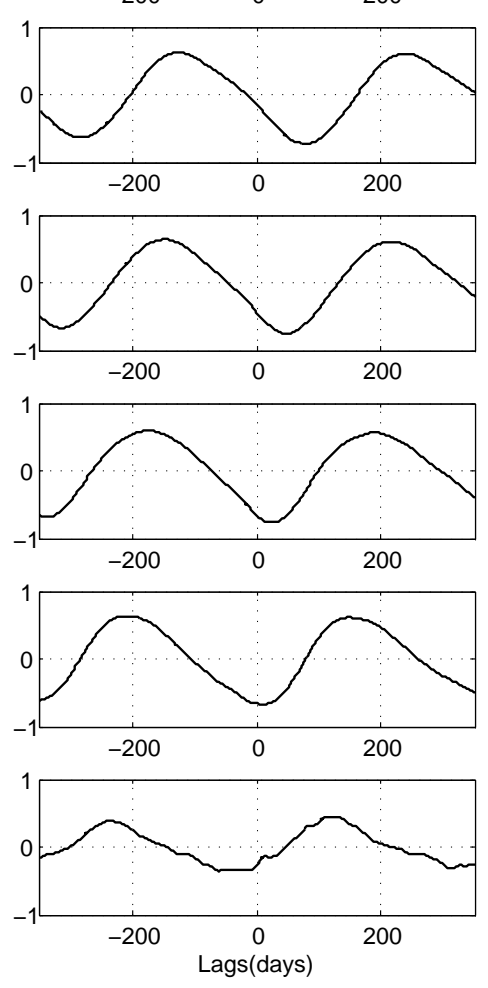
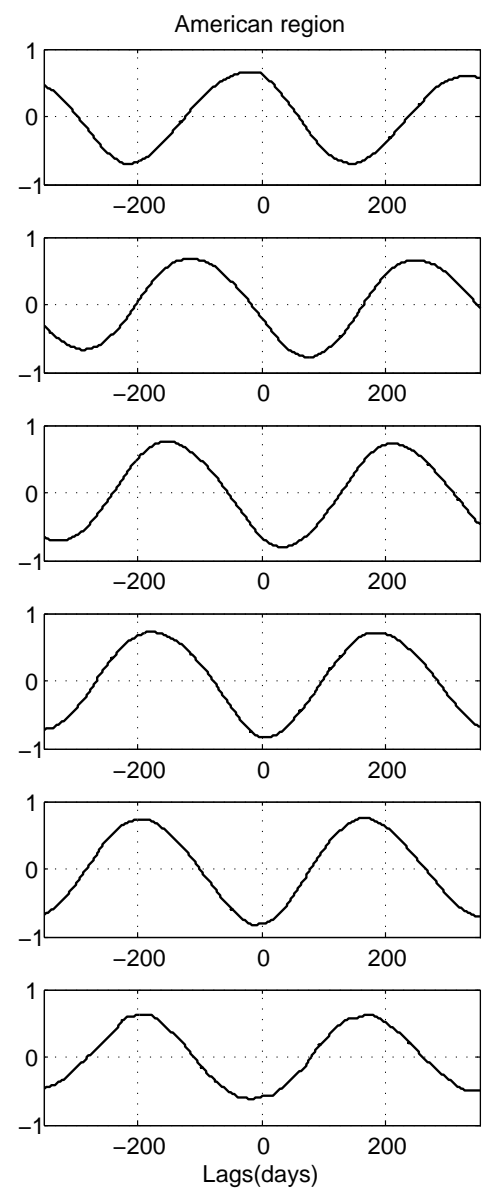

Fig. 5. The cross-correlation function computed using OLR and WVMR time series at different pressure levels viz. 146.8, 121.2 100.0, 82.5, 68.1 and $56.2 \mathrm{hPa}$.

(Figs. 3 and 6). This suggests that the convective transport plays a significant role up to $\sim 121.2 \mathrm{hPa}$ pressure level along with the large scale diabatic ascent. The influence of convective transport appears to be ceasing from 121.2 to $82.5 \mathrm{hPa}$ and slow diabatic ascent of water vapour appears to dominate for the heights above $82.5 \mathrm{hPa}$. This is to be noted that the few deep convective events may have penetrated heights above $121.2 \mathrm{hPa}$. Such events may have been averaged out as the present analysis is on a mesoscale level. Thus, $121.2 \mathrm{hPa}$ represents the average pressure level up to which convective transport dominates.

Figure 6 also includes the cross-correlation function of temperature (dashed line) which is calculated in a similar manner as described above. It is clear from Fig. 6 that the cross-correlation function peaks at zero lag values for all pressure ranges. A minimal delay of 1-2 days from 146.8 to $56.2 \mathrm{hPa}$ is observed in temperature time series suggesting that temperature signal has been transmitted spontaneously over all three convective regions. Figure 6 also shows that the cross-correlation function of temperature calculated at pressure level $100 \mathrm{hPa}$ and higher possesses a less smooth sinusoidal waveform as compared to the lower pressure levels.
This appears to be due to the anomalous increase in temperature values during boreal winter season as discussed earlier.

Figure 7 shows the mesoscale vertical ascent rate of water vapour calculated by using AURA MLS data over all three convective regions. The WVMR time series is available at various pressure levels (146.8, 121.2 and so on) of UTLS. It has been observed in Fig. 3 that WVMR time series signal is delayed while propagating from one pressure level to another. The vertical ascent rate of water vapour is defined as $\frac{\Delta h}{\Delta t}$, where $\Delta h$ signifies the pressure difference between the two successive levels and $\Delta t$ signifies the time delay in the WVMR signal propagation between these two pressure levels. Here, $\Delta t$ is defined as the time difference in terms of lag at which the correlation function peaks as shown in Fig. 6. This methodology is similar to the one developed by Niwano et al. (2003) and Schoeberl et al. (2008). The vertical ascent rate is shown at the average value of two pressure levels (Fig. 7). The sign of the values of vertical ascent rate is reversed in order to match the meteorological sign convention where the negative value of the vertical ascent rate indicates the rising air. The magnitudes of vertical ascent rate within pressure ranges $146.8-121.2 \mathrm{hPa}$ is not included in 

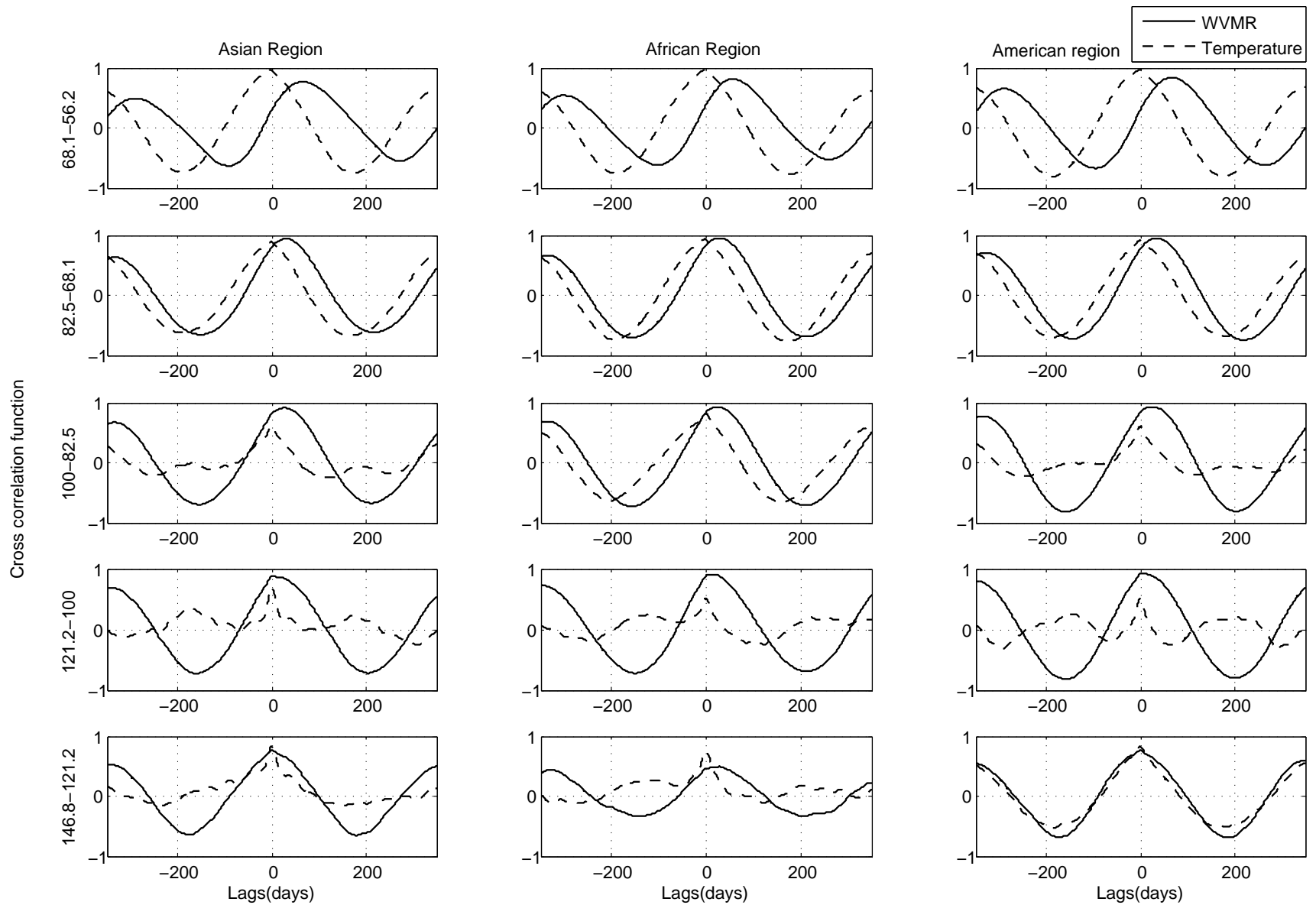

Fig. 6. The cross-correlation function of WVMR (solid line) computed using time series at two consecutive pressure levels i.e., between 146.8-121.2, 121.2-100, 100-82.5, 82.5-68.1, 68.1-56.2 hPa over Asian, American and African region. The dashed line shows the cross correlation function of temperature computed in a similar manner.

the graph over Asian and American region as the lag in this pressure range is either not detectable or less than one day. Over Asian region, there is a sharp decrease in the value of the vertical ascent rate of $121.2-100 \mathrm{hPa}$ to $100.0-82.5 \mathrm{hPa}$ (Fig. 7). Higher vertical ascent rate suggests the occurrence of a fast transport suggesting the influence of convection extends around 121.2-100 $\mathrm{hPa}$ pressure range. Above $82.5 \mathrm{hPa}$, the transport of water vapour may be rather slow and diabatic ascent of water vapour appears to dominate. American region also shows a similar phenomenon, however, the magnitude of the vertical ascent rate at $121.2-100 \mathrm{hPa}$ is less as compared to the Asian region. Over African region, the profile of vertical ascent rate is somewhat different from the other two regions. The vertical ascent rate was found to be increasing from $146.8-121.2 \mathrm{hPa}$ to $121.2-100 \mathrm{hPa}$ and decreasing thereon. This shows that water vapour over all three convective regions have different velocities at higher pressure levels suggesting the influence of "local" phenomena such as convective activities. It is interesting to note that the vertical ascent rate of water vapour for lower pressure levels $(<82.5 \mathrm{hPa})$ matches over all three regions.

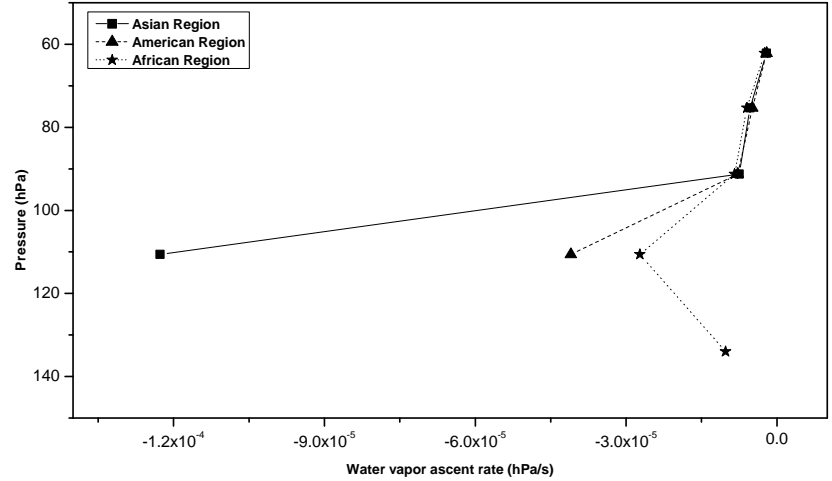

Fig. 7. Height profiles of water vapour vertical ascent rate $\left(\mathrm{hPa} \mathrm{s}^{-1}\right)$ computed using AURA MLS data over Asian, American and African regions.

The WV ascent rate and tropical upwelling in the lower stratosphere have also been estimated by Mote et al. (1998), Niwano et al. (2003), Schoeberl et al. (2008) and Fujiwara et al. (2010). The values of vertical ascent rate obtained in 
this study are comparable with the values given by Schoeberl et al. (2008) and Fujiwara et al. (2010). These values are also compared with ERA-Interim vertical velocity (refer supplementary data). A good agreement between AURA MLS vertical ascent rate and ERA-Interim vertical velocity is observed for pressure levels lower than $82.5 \mathrm{hPa}$. This is to be noted that the water vapour ascent rates presented in this analysis represent the average mesoscale ascent rates over each region. The water vapour ascent rate directly over the convective system (i.e., microscale velocities) or in-cloud ascent rate may be much different than the mesoscale ascent rate presented here (Dhaka et al., 2003).

\section{Discussion}

\subsection{Upward transport processes in TLS}

The observations presented and discussed in Sect. 3.3 suggest that convective transport of water vapour dominates up to $146.8-121.2 \mathrm{hPa}$ and mesoscale diabatic transport is prominent at heights above $\sim 82.5 \mathrm{hPa}$ level. The influence of convective transport appears to be gradually decreasing from 121.2 to $82.5 \mathrm{hPa}$.

Mesoscale diabatic transport is one of the processes that could cause hydration of TLS. However, there are other processes which could play a significant role. Injection of water across the tropopause by land convection overshooting of ice crystals up to $19 \mathrm{~km}$ followed by their sublimation (Nielsen et al., 2007; Corti et al., 2008; De Reus et al., 2008; Khaykin et al., 2009) is another process that could hydrate TLS. Another process of hydration of TLS has been suggested by Wang $(2003,2004,2007)$ and Wang et al. (2009). These authors identified a deep convective transport mechanism of water vapour through the tropopause. These authors postulated that storm top gravity wave breaking can inject tropospheric water substance into the lower stratosphere. Wang (2004) suggested that jumping cirrus is precisely the product of gravity wave breaking proposed by Wang (2003). Wang et al. (2009) used high resolution images from MODIS satellite and also supporting ground based measurements to provide direct evidence of jumping cirrus phenomena. The ice crystals in jumping cirrus are also likely to sublimate (under favourable conditions) after reaching the higher heights in the tropical lower stratosphere and the water vapour released from the ice particles transported by the jumping cirrus phenomena or convection may also undergo diabatic transportation after its detachment from the main ice system. It may also be mentioned here that if water can be transported by this mechanism then it is possible for other trace species (gases or aerosols) to be transported. This could result in enhanced $\mathrm{HDO} / \mathrm{H}_{2} \mathrm{O}$ ratio observed in the lower stratosphere (Hanisco et al., 2007). It may also be noted that vertical velocity associated with a gravity wave breaking events above convection systems may be much larger $\left(\sim 1 \mathrm{~m} \mathrm{~s}^{-1}\right)$ than the mesoscale vertical ascent rate of water vapour presented (Dhaka et al., 2003) here. However, large vertical velocities, as mentioned here, are likely to be limited mainly to the area of convective activity. The mechanism of ice sublimation and dynamical process associated with the gravity wave breaking and cirrus jumping are the complementary processes which may participate in the hydration of the tropical lower stratosphere (TLS). However, the quantitative contribution of different mechanisms in hydration of the tropical lower stratosphere still remains an open question.

\subsection{Role of horizontal transport}

In addition to vertical transport, horizontal outflow appears to be playing a major role in the water vapour redistribution at different pressure levels over the tropical region. High WVMR over the three convective regions is readily visible, but all three convective regions are also interlinked through a channel of uniformly spread moisture content (Fig. 2ab). The impact of horizontal outflow appears to be more at higher heights $(<121.2 \mathrm{hPa})$ and particularly during the later months of monsoon. Homogenisation of the hydrated layer across the globe occurs during the month of August and September (Fig. 2a) indicating the role of horizontal transport. Wind vectors obtained from Era-Interim reanalysis data show the diverging wind patterns over Asian and American region during the monsoon period. This suggests that wind may have a role in the gradual amalgamation of three high WVMR regions occurring at 121.2 and $100 \mathrm{hPa}$ pressure levels during July to September 2007 (see supplementary data).

\subsection{More moistening over the tropical American region near $100-82.5 \mathrm{hPa}$}

In Sects. 3.1 and 3.2, convection associated hydration is observed to be maximum over the Asian region. OLR and cloud top pressure data also indicate that convection over Asian region is intense and spread over a large spatial area in comparison with American or African region. But in results, larger moistening is observed over American region during the later part of monsoon near the tropopause level (100-82.5 hPa). The possible processes which could result in enhanced water vapour at the pressure levels between $100-82.5 \mathrm{hPa}$ levels over American region as compared to Asian region during the later part of monsoon season are (a) loss of water vapour in the upward transport processes over Asian region (b) inflow of water vapour which may be entrapped due to the strong horizontal winds over the American region (c) a comparatively fast vertical transport of water vapour over American region or (d) more frequent gravity wave breaking giving rise to cirrus jumping and subsequent enhanced sublimation of ice clouds/crystals over the American region. The role of each of these processes needs a detail examination. 


\subsection{Anomalous increase in temperature during winters}

In Sect. 3.3, a sudden increase in temperature is observed over all three convective regions during the winter period in the pressure range 100 to $261 \mathrm{hPa}$. However, no striking change in WVMR or OLR values is observed during the time period in which temperature peaks appear. Furthermore, convection is absent over the selected regions during the boreal winter period (OLR $>260 \mathrm{~W} \mathrm{~m}^{-2}$ ). Thus, convection may not be the source of such change in temperature. This is another interesting feature which is observed in this analysis and the reason of this increase must be inspected in details.

\section{Conclusions}

Spatial variability of water vapour over three convective regions and the transport of water vapour in the tropical UTLS have been examined using EOS AURA MLS, ISCCP D1 and NOAA OLR data over various convective regions of the tropics for the Northern Hemisphere monsoon period. Analysis of this long-term water vapour data (2004-2010) has brought out a few key features of water vapour distribution in the UTLS as summarised below:

1. Three independent convective regions with considerably low OLR $\left(<220 \mathrm{~W} \mathrm{~m}^{-2}\right)$ and different spatial extent are observed over tropics: Asian, American and African region during boreal monsoon season. Spatial distribution of cloud top pressure and the magnitude of WVMR suggests that organised convection is stronger over the Asian region as compared to American or African region. High-altitude convective clouds with top pressure of the order of 150-200 hPa generally occur in the vicinity of the maximum WVMR region. Maximum moistening of the tropical lower stratosphere and homogenisation of the hydrated layer across the globe is observed during the later months of monsoon (i.e., August and September).

2. Distribution of WVMR in the upper troposphere and lower stratosphere seems to be closely connected to these convective regions. At lower heights (> $121.2 \mathrm{hPa}$ ), moisture content over Asian region is relatively higher as compared to American and African region, whereas, at higher heights $(<121.2 \mathrm{hPa})$ WVMR over American region becomes comparable or more than the other two regions. Probable processes which may give rise to this anomaly are discussed.

3. The perturbations in temperature are observed to be transmitted spontaneously from 146.8 to $56.2 \mathrm{hPa}$ pressure level. Peak of the cross correlation function calculated by using temperature time series at consecutive pressure levels is shifted by a minimal time lag of 12 days from 146.8 to $56.2 \mathrm{hPa}$.
4. An attempt has been made to calculate the vertical ascent rate of water vapour using MLS data. The vertical ascent rate obtained from cross-correlation analysis suggests the occurrence of a fast convective transport of water vapour up to $146.8-121.2 \mathrm{hPa}$. Slow diabatic ascent of water vapour appears to dominate for heights above $100-82.5 \mathrm{hPa}$. The vertical ascent rate calculated using MLS data are comparable with the values given by Schoeberl et al. (2008).

Mesoscale slow diabatic transport is an important process of hydration of the tropical TLS. In addition to it, other processes such as cirrus jumping due to gravity waves breaking and subsequent sublimation of ice under favourable conditions in TLS can also be equally important. The transport of water vapour in TLS can be governed by any or a combination of the above mentioned processes. However, the quantitative contribution of each mechanism in hydration of TLS still remains an open question.

5. The temporal distribution of temperature shows the anomalous increase in temperature values at lower heights of UTLS region (i.e., 146.8 to $100 \mathrm{hPa}$ ) during boreal winters. Such increment in temperature is observed every year (2004-2010) over all the three convective regions. This phenomenon is limited up to $100 \mathrm{hPa}$ over all three convective regions and appears to be prominent in the pressure range of $261.0-100.0 \mathrm{hPa}$.

\section{Supplementary material related to this article is available online at: http://www.ann-geophys.net/31/967/ 2013/angeo-31-967-2013-supplement.pdf.}

Acknowledgements. We gratefully acknowledge EOS AURA MLS and Goddard Earth Sciences Data and Information Services Center for providing water vapour and temperature data. The ISCCP D1 data were obtained from the International Satellite Cloud Climatology Project data archives at, NASA Langley Research Center, Atmospheric Science Data Center. ERA-Interim reanalysis-1 data is obtained from the ECMWF data portal and OLR data from the NOAA website. We are thankful to Vivek Panwar for his helpful discussions during the initial stages of this work. We are thankful to William B. Rossow for supporting us in making use of ISCCPD1 dataset. We are also thankful to the anonymous reviewer for his valuable suggestions. This work is funded by ISRO/DOS under CAWSES India programme. We are thankful to Director, NPL and Head RASD, NPL for their support to carry out this research work.

Topical Editor P. Drobinski thanks one anonymous referee for her/his help in evaluating this paper.

\section{References}

Bannister, R. N., O’Neill, A., Gregory, A. R., and Nissen, K. M.: The role of the south east Asian monsoon and other seasonal fea- 
tures in creating the "tape-recorder" signal in the Unified Model, Q. J. Roy. Meteorol. Soc., 130, 1531-1554, 2004.

Brewer, A. W.: Evidence for a world circulation provided by the measurements of helium and water vapour distribution in the stratosphere, Q. J. Roy. Meteorol. Soc., 75, 351-363, 1949.

Corti, T., Luo, B. P., De Reus, M., Brunner, D., Cairo, F., Mahoney, M. J., and Peter, T.: Unprecedented evidence for deep convection hydrating the tropical stratosphere, Geophys. Res. Lett., 35, L10810, doi:10.1029/2008GL033641, 2008.

de Reus, M., Borrmann, S., Bansemer, A., Heymsfield, A. J., Weigel, R., Schiller, C., Mitev, V., Frey, W., Kunkel, D., Kürten, A., Curtius, J., Sitnikov, N. M., Ulanovsky, A., and Ravegnani, F.: Evidence for ice particles in the tropical stratosphere from in-situ measurements, Atmos. Chem. Phys., 9, 6775-6792, doi:10.5194/acp-9-6775-2009, 2009.

Dessler, A. E.: The effect of deep, tropical convection on the tropical tropopause layer, J. Geophys. Res., 107, 4033, doi:10.1029/2001JD000511, 2002.

Dessler, A. E. and Sherwood, S. C.: Effect of convection on the summertime extratropical lower stratosphere, J. Geophys. Res., 109, D23301, doi:10.1029/2004JD005209, 2004,.

Dhaka, S. K., Takahashi, M., Kawatani, Y., Malik, S., Shibagaki, Y., and Fukao, S.: Observations of deep convective updrafts in tropical convection and their role in the generation of gravity waves, J. Meteor. Soc. Japan, 81, 1185-1199, 2003.

Folkins, I. M., Loewenstein, M., Podolske, J., Oltmans, S. J., and Proffitt, M.: A barrier to vertical mixing at $14 \mathrm{~km}$ in the tropics: Evidence from ozonesondes and aircraft measurements, Geophys. Res. Lett., 104, 22095-22102, 1999.

Foster, P. M. de F. and Shine, K. P.: Stratospheric water vapour changes as a possible contributor to observed stratospheric cooling, Geophys. Res. Lett., 26, 3309-3312, 1999.

Fueglistaler, S., Bonazzola, M., Haynes, P. H., and Peter, T.: Stratospheric water vapour predicted from the Lagrangian temperature history of air entering the stratosphere in the tropics, J. Geophys. Res., 110, D08107, doi:10.1029/2004JD005516, 2005.

Fueglistaler, S., Dessler, A. E., Dunkerton, T. J., Folkins, I., Fu, Q., and Mote, P. W.: Tropical tropopause layer, Rev. Geophys., 47, RG1004, doi:10.1029/2008RG000267, 2009.

Fujiwara, M., Vömel, H., Hasebe, F., Shiotani, M., Ogino, S.Y., Iwasaki, S., Nishi, N., Shibata, T., Shimizu, K., Nishimoto, E., Valverde Canossa, J. M., Selkirk, H. B., and Oltmans, S. J.: Seasonal to decadal variations of water vapour in the tropical lower stratosphere observed with balloon-borne cryogenic frost point hygrometers, J. Geophys. Res., 115, D18, doi:10.1029/2010JD014179, 2010.

Gettelman, A., Salby, M. L., and Sassi, F.: Distribution and influence of convection in the tropical tropopause region, J. Geophys. Res., 107, 4080, doi:10.1029/2001JD001048, 2002.

Hanisco, T. F., Moyer, E. J., Weinstock, E. M., Clair, J. S., Sayres, D. S., Smith, J. B., and Bui, T. P.: Observations of deep convective influence on stratospheric water vapour and its isotopic composition, Geophys. Res. Lett., 34, L04814, doi:10.1029/2006GL027899, 2007.

Highwood, E. J. and Hoskins, B. J.: The tropical tropopause, Q. J. Roy. Meteorol. Soc., 124, 1579-1604, 1998.

Holton, J. R. and Gettelman, A.: Horizontal transport and the dehydration of the stratosphere, Geophys. Res. Lett., 28, 2799-2802, 2001.
Holton, J. R., Haynes, P. H., McIntyre, M. E., Douglass, A. R., Rood, R. B., and Pfister, L.: Stratosphere-troposphere exchange, Rev. Geophys., 33, 403-439, 1995.

Jain, A. R., Das, S. S., Mandal, T. K., and Mitra, A. P.: Observations of extremely low tropopause temperature over the Indian tropical region during monsoon months: Possible Implications, J. Geophys. Res., 111, D07106, doi:10.1029/2005JD005850, 2006.

Jain, A. R., Panwar, V., Mandal, T. K., Rao, V. R., Goel, A., Gautam, R., Das, S. S., and Dhaka, S. K.: Mesoscale convection system and occurrence of extreme low tropopause temperatures: observations over Asian summer monsoon region, Ann. Geophys., 28, 927-940, doi:10.5194/angeo-28-927-2010, 2010.

Jain, A. R., Panwar, V., Johny, C. J., Mandal, T. K., Rao, V. R., Gautam, R., and Dhaka, S. K.: Occurrence of extremely low cold point tropopause temperature during summer monsoon season: ARMEX campaign and CHAMP and COSMIC satellite observations, J. Geophys. Res., 116, D03102, doi:10.1029/2010JD014340, 2011.

James, R., Bonazzola, M., Legras, B., Surbled, K., and Fueglistaler, S.: Water vapor transport and dehydration above convective outflow during Asian monsoon, Geophys. Res. Lett., 35, L20810, doi:10.1029/2008GL035441, 2008.

Khaykin, S., Pommereau, J.-P., Korshunov, L., Yushkov, V., Nielsen, J., Larsen, N., Christensen, T., Garnier, A., Lukyanov, A., and Williams, E.: Hydration of the lower stratosphere by ice crystal geysers over land convective systems, Atmos. Chem. Phys., 9, 2275-2287, doi:10.5194/acp-9-2275-2009, 2009.

Lambert, A., Read, W. G., Livesey, N. J., Santee, M. L., Manney, G. L., Froidevaux, L., Wu, D. L., Schwartz, M. J., Pumphrey, H. C., Jimenez, C., Nedoluha, G. E., Cofield, R. E., Cuddy, D. T., Daffer, W. H., Drouin, B. J., Fuller, R. A., Jarnot, R. F., Knosp, B. W., Pickett, H. M., Perun, V. S., Snyder, W. V., Stek, P. C., Thurstans, R. P., Wagner, P. A., Waters, J. W., Jucks, K. W., Toon, G. C., Stachnik, R. A., Bernath, P. F., Boone, C. D., Walker, K. A., Urban, J., Murtagh, D., Elkins, J. W., and Atlas, E.: Validation of the Aura Microwave Limb Sounder middle atmosphere water vapour and nitrous oxide measurements, J. Geophys. Res., 112, D24S36, doi:10.1029/2007JD008724, 2007.

Liebmann, B. and Smith, C. A.: Description of a Complete (Interpolated) Outgoing Longwave Radiation Dataset, B. Am. Meteorol. Soc., 77, 1275-1277, 1996.

Mote, P.: The annual cycle of stratospheric water vapour in a general circulation model, J. Geophys. Res., 100, 7363-7379, 1995.

Mote, P., Rosenlof, K., Mclntyre, M., Carr, E., Gille, J., Holton, J., Kinnersley, J., Pumphrey, H., Russell III, J., and Waters, J.: An atmospheric tape recorder: The imprint of tropical tropopause temperatures on stratospheric water vapour, J. Geophys. Res., 101, 3989-4006, 1996.

Mote, P. W., Dunkerton, T. J., McIntyre, M. E., Ray, E. A., Haynes, P. H., and Russell III, J. M.: Vertical velocity, vertical diffusion, and dilution by midlatitude air in the tropical lower stratosphere, J. Geophys. Res., 103, 8651-8666, 1998.

Nielsen, J. K., Larsen, N., Cairo, F., Di Donfrancesco, G., Rosen, J. M., Durry, G., Held, G., and Pommereau, J. P.: Solid particles in the tropical lowest stratosphere, Atmos. Chem. Phys., 7, 685695, doi:10.5194/acp-7-685-2007, 2007.

Niwano, M., Yamazaki, K., and Shiotani, M.: Seasonal and QBO variations of ascent rate in the tropical lower stratosphere as inferred from UARS HALOE trace gas data, J. Geophys. Res., 108, 
4794, doi:10.1029/2003JD003871, 2003.

Panwar, V., Jain, A. R., Goel, A., Mandal, T. K., Rao, V. R., and Dhaka, S. K.: Some features of water vapour mixing ratio in tropical upper troposphere and lower stratosphere: Role of convection, Atmos. Res., 108, 86-103, doi:10.1016/j.atmosres.2012.02.003, 2012.

Ricaud, P., Barret, B., Attié, J.-L., Motte, E., Le Flochmoën, E., Teyssèdre, H., Peuch, V.-H., Livesey, N., Lambert, A., and Pommereau, J.-P.: Impact of land convection on tropospherestratosphere exchange in the tropics, Atmos. Chem. Phys., 7, 5639-5657, doi:10.5194/acp-7-5639-2007, 2007.

Rossow, W. B. and Schiffer, R. A.: Advances in understanding clouds from ISCCP, B. Am. Meteorl. Soc., 80, 2261-2288, 1999.

Rossow, W. B., Walker, A. W., Beuschel, D. E., and Roiter, M. D.: International Satellite Cloud Climatology Project (ISCCP) Documentation of New Cloud Datasets. WMO/TD-No. 737, World Meteorological Organization, 115 pp., 1996.

Schoeberl, M. R., Douglass, A. R., Stolarski, R. S., Pawson, S., Strahan, S. E., and Read, W.: Comparison of lower stratospheric tropical mean vertical velocities, J. Geophys. Res., 113, D24109, doi:10.1029/2008JD010221, 2008.

Schwartz, M. J., Lambert, A., Manney, G. L., Read, W. G., Livesey, N. J., Froidevaux, L., Ao, C. O., Bernath, P. F., Boone, C. D., Cofield, R. E., Daffer, W. H., Drouin, B. J., Fetzer, E. J., Fuller, R. A., Jarnot, R. F., Jiang, J. H., Jiang, Y. B., Knosp, B. W., Krüger, K., Li, J.-L. F., Mlynczak, M. G., Pawson, S., Russell III, J. M., Santee, M. L., Snyder, W. V., Stek, P. C., Thurstans, R. P., Tompkins, A. M., Wagner, P. A., Walker, K. A., Waters, J. W., and Wu, D. L.: Validation of the Aura Microwave Limb Sounder temperature and geopotential height measurements, J. Geophys. Res., 113, D15S11, doi:10.1029/2007JD008783, 2008.
Sherwood, S. C. and Dessler, A. E.: A model for transport across the tropical tropopause, J. Atmos. Sci., 58, 765-779, 2001.

Solomon, S., Garcia, R. R., Rowland, F. S., and Wuebles, D. J.: On the depletion of Antarctic ozone, Nature, 321, 755-758, 1986.

Wang, P. K.: Moisture plumes above thunderstorm anvils and their contributions to cross tropopause transport of water vapour in midlatitudes, J. Geophys. Res., 108, 4194, doi:10.1029/2002JD002581, 2003.

Wang, P. K.: A cloud model interpretation of jumping cirrus above storm top, Geophys. Res. Lett. 31, L18106, doi:10.1029/2004GL020787, 2004.

Wang, P. K.: The thermodynamic structure atop a penetrating convective thunderstorm, Atmos. Res., 83, 254-262, 2007.

Wang, P. K., Setvák, M., Lyons, W., Schmid, W., and Lin, H.-M.: Further evidence of deep convective vertical transport of water vapor through the tropopause, Atmos. Res., 94, 400-408, 2009.

Wild, M. and Roeckner, E.: Radiative fluxes in the ECHAM5 general circulation model, J. Climate, 19, 3792-3809, doi:10.1175/JCLI3823.1, 2006. 